\title{
Cryo micro-spectroscopy at ID21 for environmental sciences
}

Marine Cotte $^{1}$, Hiram Castillo-Michel ${ }^{1}$, Ana Elena Pradas del Real ${ }^{1}$, Murielle Salomé ${ }^{1}$, David Bugnazet ${ }^{1}$, Wout De Nolf ${ }^{1}$ ${ }^{1}$ Id21, Esrf, Grenoble, France

E-mail: cotte@esrf.fr

It is well recognized that, in terms of availability and toxicity in the environment, metal speciation is more important than total concentration. Metal speciation determines the distribution of an element in tissues and ultimately the various mechanisms of toxicity and detoxification. The chemical form and distribution of a metal are also important for environmental risk assessment. In this sense, the development of non-destructive microspectroscopic techniques, as available at ESRF beamline ID21, is of special interest to study the fate of metals in the environment $[1,2]$.

Localization and speciation of trace elements at ID21 is done using micro-X-ray fluorescence ( $\mu$ XRF) and micro $X$-ray absorption spectroscopy ( $\mu$-XANES) in the tender X-ray domain (2.0-9.1 keV) [3]. The X-ray beam is focused using KB optics to a sub-micron spot $(\sim 500 \mathrm{~nm})$, which then allows localization of trace elements at subcellular level. The beamline is equipped with a passively cooled cryogenic stage that allows the study of frozen hydrated specimens (cells and cryosectioned tissues) preventing elemental redistribution and minimizing radiation damage. The combination of $\mu \mathrm{XRF}$ and $\mu X A N E S$ allows precise localization and speciation of biologically relevant $(\mathrm{P}, \mathrm{S}, \mathrm{Cl}, \mathrm{Ca}, \mathrm{K}$ ) and potentially toxic elements (Cd, $\mathrm{Ag}, \mathrm{Ti}, \mathrm{La}, \mathrm{Ce}$ ) in complex samples with detection limits in the low femtogram range.

This presentation will highlight experiments performed at ID21 taking full advantage of the beamline capabilities in the study of metal accumulation in plants, interaction of plants with engineered nanomaterials (ENMs) and detection of ENMs in complex matrices [1].

[1] Castillo-Michel, H., Larue, C., Pradas del Real, A., Cotte, M. \& Sarret, G. (2016). Plant Physiol. Biochem. 110, 13-32.

[2] Sarret, G., Pilon Smits, E.A.H., Castillo-Michel, H., Isaure, M.P., Zhao, F.J., Tappero, R. (2013). Advances in Agronomy $119,1-82$.

[3] Salome, M., Cotte, M., Baker, R., Barret, R., Benseny-Cases, N., Berruyer, G., Bugnazet, D., Castillo-Michel, H., Cornu, C., Fayard, B., Galiardini, E., Hino, R., Morse, J., Papillon, E., Pouyet, E., Rivard, C., Sole, V.A., Susini, J., \& Veronesi, G. (2013). J. of Phys. 425, 182004.

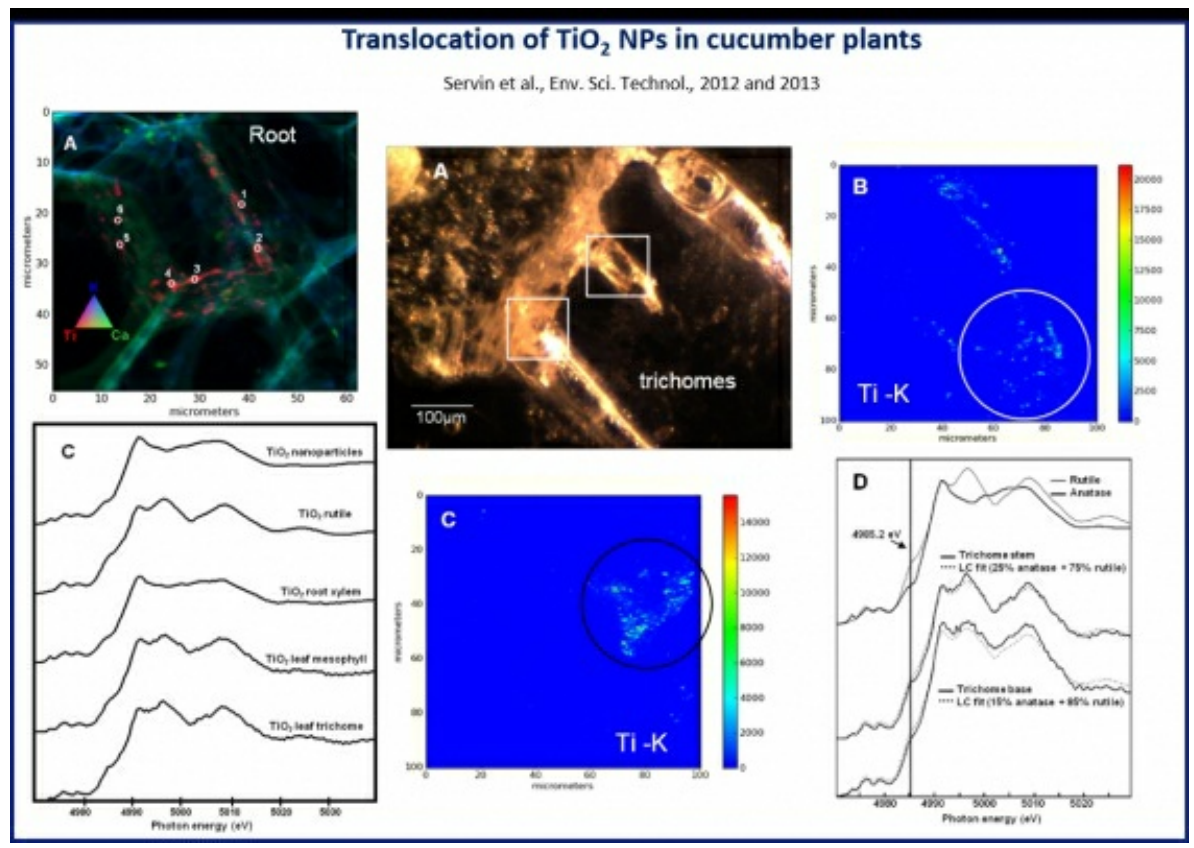

Keywords: nanomaterials 